\title{
Vegetative propagation of mature dragon trees through epicormic shoots
}

\author{
Propagación vegetativa de quiri por intermedio de brotes epicórmicos
}

\author{
Carlos A Stuepp a*, Katia C Zuffellato-Ribas ${ }^{\text {b }}$, Ivar Wendling c, \\ Henrique S Koehler ${ }^{a}$, Cleusa Bona ${ }^{b}$
}

\begin{abstract}
*Corresponding author: a Universidade Federal do Paraná, Departamento de Fitotecnia e Fitossanitarismo, Caixa postal 19061, Rua dos Funcionários 1540, Curitiba-PR, Brasil, tel/fax.: +554133505601, carlosandrehc@hotmail.com

b Universidade Federal do Paraná, Departamento de Botânica, Curitiba-PR, Brazil. ${ }^{c}$ Embrapa, Centro Nacional de Pesquisa de Florestas, Colombo-PR, Brazil.
\end{abstract}

\begin{abstract}
SUMMARY
Epicormic shoots were induced in stumps and detached branches of adult Paulownia fortunei var. mikado plants to evaluate rooting potential. Stem cuttings obtained from shoots of stump were prepared with $12 \mathrm{~cm}$ in length and two leaves reduced to $78.5 \mathrm{~cm}^{2}(10$ cm diameter). Cuttings from shoots of branches were prepared with 8-10 cm in length, and two leaves reduced to $50 \%$ of the original size. Anatomical analysis was performed to evaluate possible barriers to rhizogenesis. After disinfestation, indolebutyric acid (IBA) was applied $\left(0,500,1,000,1,500\right.$ and 2,000 mg L-1). Installation was made in plastic pots with a volume of $170 \mathrm{~cm}^{3}$ and $53 \mathrm{~cm}^{3}$, respectively for each type of cuttings, with fine vermiculite and carbonized rice hulls $(1: 1 \mathrm{v} / \mathrm{v})$ as substrate. After 60 days in a greenhouse, cuttings from epicormic shoots of branches presented rooting (58.12\%) and the average length of the three longest roots/ cutting $(4.76 \mathrm{~cm})$ was higher than in cuttings from stumps. The highest number of roots/cutting (7.66) and percentage of cuttings with callus (27.50) was observed in cuttings from stumps. There were no anatomical barriers observed harming the roots formation in the two types of cuttings. The use of indolebutyric acid is not required to induce rooting.
\end{abstract}

Key words: auxins, cuttings, Paulownia fortunei var. mikado.

\section{RESUMEN}

Brotes epicórmicos fueron inducidos en cepas y ramas desprendidas de árboles maduros de Paulownia fortunei var. mikado (quiri) para evaluar el potencial de enraizamiento. Estacas provenientes de brotes de las cepas se prepararon con $12 \mathrm{~cm}$ de longitud y dos hojas reducidas a 78,5 cm² (10 cm de diámetro), estacas de brotes de ramas desprendidas se prepararon con 8-10 cm de longitud y dos hojas reducidas a $50 \%$ del tamaño original. Se realizó un análisis anatómico para evaluar las posibles barreras para el enraizamiento. Después de la desinfección se aplicó ácido indolbutírico (IBA) (0, 500, 1.000, 1.500 y $2.000 \mathrm{mg} \mathrm{L}^{-1}$ ). La instalación se hizo en tubos de $170 \mathrm{~cm}^{3}$ y $53 \mathrm{~cm}^{3}$, respectivamente, para cada tipo de estaca, con vermiculita fina y cáscara de arroz carbonizado $(1: 1, \mathrm{v} / \mathrm{v})$ como sustrato. Después de 60 días en el invernadero, estacas de brotes epicórmicos de ramas mostraron enraizamiento (58,12 \%) y longitud media de las tres raíces más largas por estaca $(4,76 \mathrm{~cm})$ mayor que en estacas provenientes de cepas. Se observó un mayor número de raíces por estaca $(7,66)$ y porcentaje de estacas con callo $(27,50)$ en las estacas de brotes epicórmicos provenientes de cepas. No se observaron barreras anatómicas perjudiciales para la respuesta rizogénica en los dos tipos de estacas. No se requiere el uso de ácido indolbutírico para inducir el enraizamiento.

Palabras clave: auxinas, estacas, Paulownia fortunei (Seem.) Hemsl. var. mikado.

\section{INTRODUCTION}

Paulownia fortunei (Seem.) Hemsl. var. mikado belongs to the Scrophulariaceae family, native to East Asia, and is commonly known as dragon tree. Out of the 15 species belonging to the Paulownia gender, the most known and cultivated are Paulownia elongata S.Y Hu, Paulownia fargesii Franch, Paulownia fortunei, Paulownia glabrata Rehder, Paulownia taiwaniana T.W Hu et H.J. Chang, and Paulownia tomentosa (Thumb) Steud (Zhu et al. 1986). This gender was also introduced in North America, Australia, Europe and Japan, with different purposes (Kumar et al. 1999).
Slowness of sexual propagation, together with the great phenotype variation of the Paulownia gender, when sexually propagated, justifies more detailed studies on asexual multiplication, giving way to vegetative propagation as an interesting method to create a great number of seedlings in a short period of time (Bergmann 1997). Meanwhile, the absence of studies providing efficient propagation protocols for this gender has reduced the use of $P$. fortunei as an alternative for Brazilian forestry.

Vegetative propagation has been widely used in forest species seedlings production. This method consists in the asexual multiplication of plant parts, thus originating 
individuals genetically identical to the stock plant to be propagated (Husen and Pal 2006, Hartmann et al. 2011). Its increasing use is due to a higher capacity in fixing the genetic gains produced by improvement programs (Wendling and Xavier 2003, Golle et al. 2009).

Maturation of woody plants is an extremely important subject, considering its direct influence on the physiological processes of plants themselves. Maturation related effects include variations of the vegetative propagation capacity, of the growth rates and forms, changes in quality and velocity of roots formation, changes in the growth characteristics, in leaves morphology and also biochemical and physiological alterations (Husen and Pal 2006).

Thus, to consider the use of techniques in order to recover superior material becomes necessary. Adult trees coppicing is one of these techniques and is widely used in other forest species. Coppicing consists in cutting clear plants that reached maturity to induce epicormic shoots emission. These shoots present an extremely fast growth because, as a general rule, they are physiologically younger than the others (Borges Júnior et al. 2004). On the other hand, the induction of epicormic shoots in detached branches is obtained using segments of branches collected from the stock plant and installed in an adequate environment, for the existing buds to generate new shoots.

This work had the purposes of studying the rooting performances of $P$. fortunei var. mikado cuttings, originated from epicormic shoots of adult trees stumps and from epicormic shoots of detached branches, through application of indolebutyric acid in different concentrations, and also of performing anatomical and histochemical analyses to investigate possible barriers to formation of adventitious roots.

\section{METHODS}

In July 2011, fifteen adult Dragon tree stock plants, approximately 20 years old, were coppiced in order to later collect shoots from the stumps. In August 2011, branches were collected from other stock plants at approximately 10 meters from the ground. Branches were then standardized with a length of $60 \mathrm{~cm}$ and diameters from 10 to $15 \mathrm{~cm}$. In order to use shoots from these detached branches, they were stocked and maintained in a greenhouse. Stock plants were located in the municipality of Aurora-SC, Brazil (27 $23^{\prime}$ 28.57" $\mathrm{S}$ and $49^{\circ} 38^{\prime} 43.30^{\prime \prime} \mathrm{W}$ ), at an approximate altitude of $700 \mathrm{~m}$. The climate of this region is classified as $\mathrm{Cfa}$, or humid subtropical climate. Average temperature in the coldest month was lower than $18{ }^{\circ} \mathrm{C}$ (mesothermal), and average temperature of the hottest month was higher than $22^{\circ} \mathrm{C}$; presenting hot summers, rare icing during winter and rain events concentrated in the summer months, although without a well defined dry season.

To perform the rooting experiments in October 2011, shoots of dragon tree were collected from stumps and from branches still maintained in a greenhouse. Experiments were performed in the Forest Species Propagation Labo- ratory of Embrapa Forestry (National Center of Forestry Research) in Colombo-PR, Brazil.

Epicormic shoots from stumps. Shoots used in this experiment originated from stumps of approximately 20 year-old stock plants, with a diameter at breast height (DBH) of $60-80 \mathrm{~cm}$, coppiced at $2 \mathrm{~m}$ from the ground (figure 1A,B). The experiment was installed in October 2011.

Throughout the collection process on field, shoots were humidified and placed in plastic bags for later transportation to a protected environment. Semi-hardwood cuttings were then prepared starting from these shoots, with a length of 10 to $12 \mathrm{~cm}$, a bevel cut on the base and a straight cut above the last apical bud, keeping two leaves in the upper third of the cutting, with their area reduced to approximately $78.5 \mathrm{~cm}^{2}$ (10 cm diameter) in the upper third of the cutting (figure 1C).

Epicormic shoots from detached branches. The 57 branches used were obtained from approximately 20 year- old trees, detached from stock plants treetops, at a height of approximately 10 meters, standardized with a length of $60 \mathrm{~cm}$ and $10-15 \mathrm{~cm}$ diameter (figure 1D).

Branches were placed in a vertical position in direct contact with the ground (gravel), in a greenhouse with intermittent misting (temperature of $24^{\circ} \mathrm{C} \pm 2{ }^{\circ} \mathrm{C}$ and relative humidity of the air higher than $80 \%$ ), in the municipality of Colombo-PR, Brazil.

After 60 days (October 2011), epicormic shoots (figure $1 \mathrm{E})$ from branches maintained in the greenhouse were collected and cuttings were prepared with a length from 8 to $10 \mathrm{~cm}$, a bevel cut on the base and a straight cut above the last apical bud, keeping two leaves with half the original surface in the upper third of the cutting (figure 1F).

Treatments. During the preparation process, cuttings were kept in a bucket with water to avoid dehydration. After being prepared, cuttings were submitted to disinfestation with sodium hypochlorite solution at $0.5 \%$ for ten minutes (bactericide action), afterwards washed with running water for ten minutes. Subsequently, bases of cuttings were treated with indolebutyric acid (IBA), plant growth regulator, auxin, with the following treatments (T): T1 $0 \mathrm{mg} \mathrm{L}^{-1}$ (witness); T2 $500 \mathrm{mg} \mathrm{L}^{-1}$; T3: 1,000 $\mathrm{mg} \mathrm{L}^{-1}$; T4 1,500 mg $\mathrm{L}^{-1}$; T5 2,000 $\mathrm{mg} \mathrm{L}^{-1}$.

Treatments with different IBA concentrations were performed through immersion of cuttings bases into hydroalcoholic IBA solution ( $50 \% \mathrm{v} / \mathrm{v})$ for ten seconds. Cuttings of T1 treatment ( $\left.0 \mathrm{mg} \mathrm{L}^{-1} \mathrm{IBA}\right)$ were immersed into alcohol and distilled water solution (50 \% v/v) without plant growth regulator. Cuttings bases were accommodated $3 \mathrm{~cm}$ deep into $110 \mathrm{~cm}^{3}$ volume polypropylene pots filled with midsize vermiculite and carbonized rice hull $(1: 1 \mathrm{v} / \mathrm{v})$. Cuttings were then accommodated into a greenhouse with intermittent misting (temperature $24{ }^{\circ} \mathrm{C} \pm 2{ }^{\circ} \mathrm{C}$ and more than $80 \%$ relative humidity) in Colombo-PR, Brazil. 

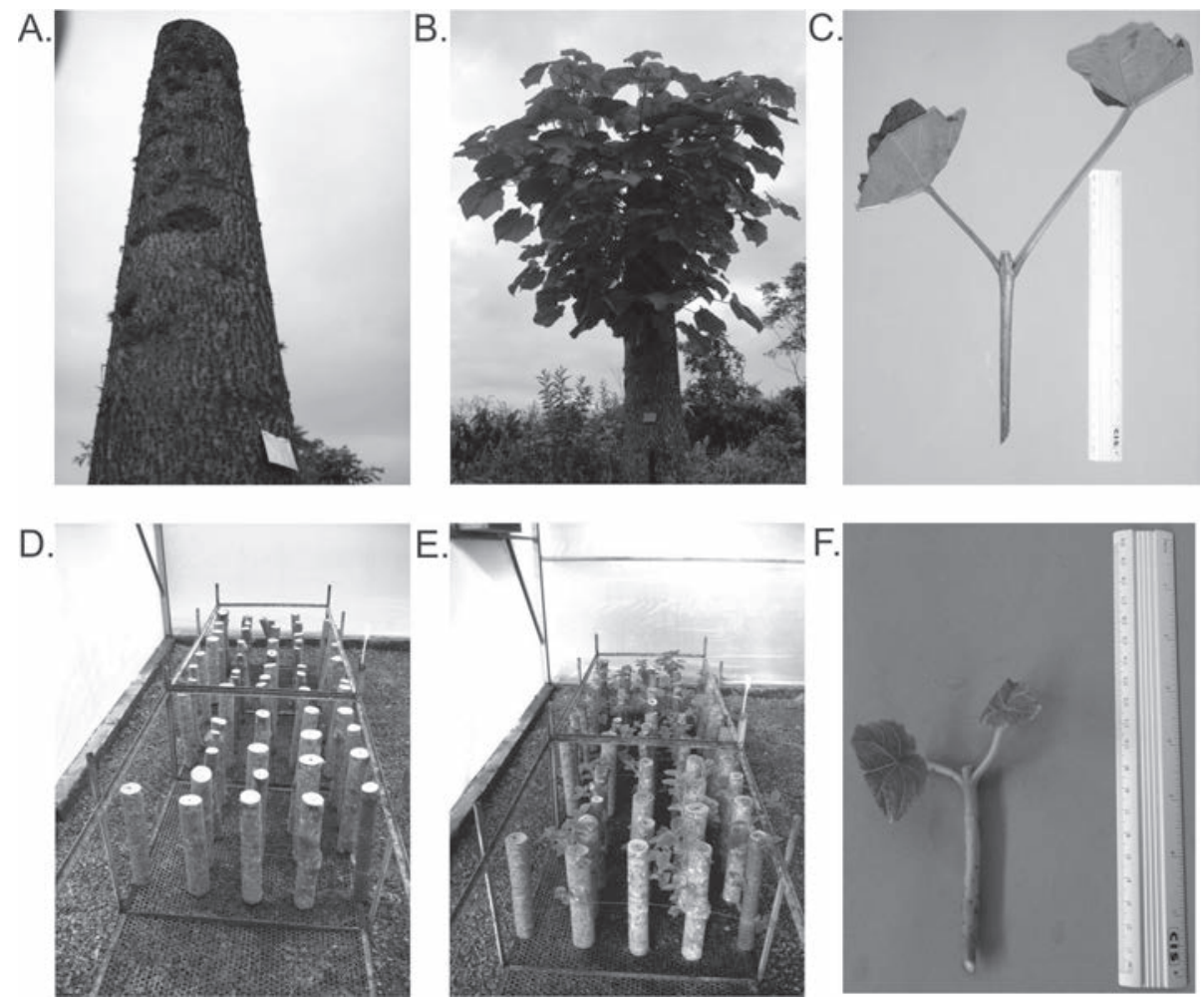

Figure 1. Epicormic shoots of Pawlonia fortunei var. Mikado. A) Stump $2.0 \mathrm{~m}$ from the ground. B) Epicormic shoots, three months after coppicing. C) General appearance of semi-hardwood cuttings. D) Branches maintained in greenhouse. E) Branches 30 days after installation, presenting epicormic shoots. F) General appearance of a semi-hardwood cutting from branches.

Brotes epicórmicos de Pawlonia fortunei var. mikado: A) Cepas, 2,0 metros del suelo. B) Brotes epicórmicos, tres meses después del rebrote. C) Apariencia general de estacas semileñosas. D) Ramas mantenidas en invernadero. E) Ramas 30 días después de la instalación, presentando brotes epicórmicos. F) Apariencia general de una estaca de ramas semileñosas.

After 45 days (epicormic shoots from detached branches) and 60 days (epicormic shoots from stumps) from the installation of the experiment, the following variables were evaluated: rooting percentage (alive cuttings presenting roots at least $2 \mathrm{~mm}$ long); number of roots per cutting; length of the three longest roots/cutting $(\mathrm{cm})$; percentage of cuttings with callus (alive cuttings without roots, but with undifferentiated cellular mass formations in the base); percentage of survival (alive cuttings that did not present roots or callus); percentage of mortality (cuttings with necrosed tissues); percentage of cuttings with shoots (alive cuttings, with or without roots or callus, presenting new leaves buds); percentage of leaves maintenance (cuttings that maintained the original leaves throughout the rooting process).

Statistical analyses. The experimental design was a completely randomized design, with $2 \times 5$ factorial arrangement (2 types of cuttings $x 5$ IBA concentrations), with four repetitions of eight cuttings per experimental unit, for a total of 320 cuttings by the end of the experiment. Treatments variance was tested for homogeneity through the Bartlett test. Variables that presented significant diffe- rences according to the $\mathrm{F}$ test had the averages compared through the Tukey test at $5 \%$ significance.

Anatomical analyses. At the same time of the experiment installation, samples of the bases, approximately $2 \mathrm{~cm}$ long, were collected from cuttings and then accommodated in FAA70 (Formalin, Acetic Acid and Ethanol) for 24 hours (Johansen 1940). Subsequently, they were conserved in alcohol $70 \%$ waiting for blocks preparation and the beginning of the anatomical analysis activity, which was performed in the Laboratory of Plant Anatomy, UFPR, Curitiba-PR, Brazil.

Material previously stocked in alcohol $70 \%$ was cut into $1.0 \mathrm{~mm}$ fragments and infiltrated in blocks with PEG (Polyethylene Glycol 1500). These blocks were then fixed with woody supports and maintained into a refrigerator during 24 hours. Subsequently, blocks were sectioned with a rotary micro cutter (Olympus CUT 4055) into slices $15 \mu \mathrm{m}$ thick.

The ribbon cuts obtained were submerged in Petri dishes with distilled water, to dissolve PEG. Cuts were then submitted to histochemical tests with lugol, to identify amid grains; ferric chloride, to identify phenolic compounds; and with sudam III, to identify lipids. Some cuts were also submitted to double coloration with safrablau 
(5 mL of safranine $1 \%$ water solution and $95 \mathrm{~mL}$ of Astra Blue $1 \%$ water solution), to identify lignin and cellulose.

After the described procedures, semi-permanent slides were prepared using glycerin gel and sealed with transparent enamel. Subsequently, slides were examined and documented with photomicrography using a ZEISS photomicroscope equipped with a Sony Cyber-shot P72 digital camera; operations were performed in the UFPR Laboratory of Phycology, Curitiba-PR, Brazil.

\section{RESULTS}

A significant difference was observed for the rooting percentage between the two types of cuttings, originated from epicormic shoots of stumps or detached branches of P. fortunei var. mikado, collected in October 2011 (spring). The best result was observed in cuttings from epicormic shoots of branches, with $58.12 \%$ (table 1 ).

About the number of roots per cutting (table 1), it is possible to notice the superiority of the cuttings made from stumps (7.66 roots/cutting), where morphological differences related to bigger diameter and size of cuttings could have helped the higher strength verified, which appeared in the form of a root system with faster formation and development. Results about the average length of the three longest roots/cutting (table 1) revealed that cuttings coming from branches were superior to the ones coming from stumps for the concentrations 0,500 and 1,500 mg $\mathrm{L}^{-1}$ IBA, with $5.06 \mathrm{~cm}, 5.84 \mathrm{~cm}$ and $5.40 \mathrm{~cm}$, respectively. Regarding the percentage of cuttings with callus (table 2), significant differences were observed between the averages of the two types of cuttings, coming from epicormic shoots of stumps and branches of $P$. fortunei var. mikado, being the best result the one observed in the cuttings coming from epicormic shoots of stumps, with $27.50 \%$.

About $P$. fortunei cuttings survival (table 2), significant differences were verified between the averages of the two types of used cuttings, being the best results obtained in cuttings coming from epicormic shoots of stumps, with $13.75 \%$ alive cuttings.

Concerning the percentage of mortality of $P$. fortunei cuttings, significant differences were observed between the averages of the two types of cuttings used, being the higher result observed in cuttings from epicormic shoots of branches, with $33.75 \%$ dead cuttings (table 2).

Results concerning leaves maintenance in $P$. fortunei cuttings revealed that the ones coming from epicormic shoots from branches were superior to the ones coming from stumps when IBA concentration was $0 \mathrm{mg} \mathrm{L}^{-1}$, presenting $15.62 \%$ cuttings with leaves at the end of the experiment. On the other hand, cuttings coming from epicormic shoots of stumps were statistically superior when IBA concentration was $500 \mathrm{mg} \mathrm{L}^{-1}$, presenting $12.50 \%$ cuttings with leaves at the end of the experiment.

Out of the averages of IBA concentrations considered for cuttings coming from stumps, the best result was ob-
Table 1. Rooting percentage, number of roots and length of the three longest roots per cutting coming from epicormic shoots of stumps or detached branches of $P$. fortunei var. mikado, submitted to treatments with different indolebutyric acids (IBA).

Porcentaje de enraizamiento, número de raíces y longitud de las tres raíces más largas por estaca procedentes de brotes epicórmicos de cepas y ramas desprendidas de $P$. fortunei var. mikado, sometidas a diferentes concentraciones de ácido indolilbutírico (IBA).

\begin{tabular}{cccc}
\hline \multicolumn{4}{c}{ Origin of Shoots } \\
\hline $\begin{array}{c}\text { IBA } \\
\text { g L L }^{-1}\end{array}$ & $\begin{array}{c}\text { Epicormic shoots } \\
\text { from stump }\end{array}$ & $\begin{array}{c}\text { Epicormic shoots } \\
\text { of branches }\end{array}$ & Averages \\
\hline \multicolumn{4}{c}{ Rooting percentage } \\
500 & 28.12 & 59.37 & $43.75 \mathrm{a}$ \\
1000 & 34.37 & 56.25 & $45.31 \mathrm{a}$ \\
1500 & 41.02 & 50.00 & $45.31 \mathrm{a}$ \\
2000 & 47.27 & 68.75 & $57.81 \mathrm{a}$ \\
\hline Averages & $41.25 \mathrm{~B}$ & 56.25 & $56.25 \mathrm{a}$ \\
\hline
\end{tabular}

Coefficient of variation $33.67 \%$

Average Number of roots/cutting

\begin{tabular}{crrrr}
0 & 2.12 & 4.06 & 3.09 & b \\
500 & 6.75 & 2.76 & 4.75 & b \\
1000 & 12.25 & 4.1 & 8.18 & a \\
1500 & 8.33 & 3.99 & 6.16 & a b \\
2000 & 8.87 & 7.09 & 7.99 & a \\
\hline Averages & $7.66 \mathrm{~A}$ & $4.40 \mathrm{~A}$ & &
\end{tabular}

Coefficient of variation $62.46 \%$

\begin{tabular}{ccrc}
\hline \multicolumn{5}{c}{ Average length of root/cutting } \\
0 & 2.2 a B & 5.06 a A & 3.63 \\
500 & 2.71 a B & 5.84 a A & 4.28 \\
1,000 & 2.72 a A & 4.17 a A & 3.45 \\
1,500 & 2.86 a B & 5.4 a A & 4.14 \\
2,000 & 4.57 a A & 3.3 a A & 3.94 \\
\hline Averages & 3.01 & 4.76 \\
\hline
\end{tabular}

Coefficient of variation $34.40 \%$

Averages followed by the same capital letter in line and lower case letter in column do not differ between them for Turkey test at $5 \%$ significance.

served with $500 \mathrm{mg} \mathrm{L}^{-1} \mathrm{IBA}$, with $12.50 \%$, statistically differing from $0,1,000$ and $1,500 \mathrm{mg} \mathrm{L}^{-1}$ IBA concentrations. For the cuttings coming from detached branches, the best results were observed with $0 \mathrm{mg} \mathrm{L}^{-1}$ IBA concentration, with $15.62 \%$, statistically differing from the other concentrations (table 3). 
Table 2. Percentage of cuttings with callus, survival and mortality in cuttings coming from epicormic shoots of stump and detached branches of $P$. fortunei var. mikado, submitted to different concentrations of indolebutyric acid (IBA) treatments.

Porcentaje de estacas con callo, supervivencia y mortalidad en estacas procedentes de brotes epicórmicos de cepas y ramas desprendidas de $P$. fortunei var. mikado, sometidas a diferentes concentraciones de ácido indolilbutírico (IBA).

\begin{tabular}{|c|c|c|c|}
\hline \multicolumn{4}{|c|}{ Types of cuttings } \\
\hline $\begin{array}{l}\text { IBA } \\
\text { mg L }^{-1}\end{array}$ & $\begin{array}{l}\text { Epicormic shoots } \\
\text { from stump }\end{array}$ & $\begin{array}{c}\text { Epicormic shoots } \\
\text { of branches }\end{array}$ & Averages \\
\hline \multicolumn{4}{|c|}{ Percentage of cuttings with callus } \\
\hline 0 & 28.12 & 9.37 & 18.75 a \\
\hline 500 & 34.37 & 6.25 & 20.31 a \\
\hline 1,000 & 31.25 & 0.00 & 15.62 a \\
\hline 1,500 & 21.87 & 0.00 & $10.94 \mathrm{a}$ \\
\hline 2,000 & 21.87 & 0.00 & 10.94 a \\
\hline Averages & $27.50 \mathrm{~A}$ & $3.12 \mathrm{~B}$ & \\
\hline \multicolumn{4}{|c|}{ Coefficient of variation $55.98 \%$} \\
\hline \multicolumn{4}{|c|}{ Percentage of survival } \\
\hline 0 & 22.27 & 0.00 & 10.94 a \\
\hline 500 & 9.37 & 6.25 & 7.81 a \\
\hline 1,000 & 12.50 & 9.37 & $10.94 \mathrm{a}$ \\
\hline 1,500 & 15.62 & 3.12 & 9.37 a \\
\hline 2,000 & 9.37 & 6.25 & 7.81 a \\
\hline Averages & $13.75 \mathrm{~A}$ & $5.00 \mathrm{~B}$ & \\
\hline \multicolumn{4}{|c|}{ Coefficient of variation $111.04 \%$} \\
\hline \multicolumn{4}{|c|}{ Percentage of mortality } \\
\hline 0 & 22.27 & 31.25 & 26.56 a \\
\hline 500 & 21.87 & 31.25 & 26.56 a \\
\hline 1,000 & 15.62 & 40.62 & 28.12 a \\
\hline 1,500 & 15.62 & 28.12 & 21.87 a \\
\hline 2,000 & 12.50 & 37.50 & $25.00 \mathrm{a}$ \\
\hline Averages & $17.50 \mathrm{~B}$ & $33.75 \mathrm{~A}$ & \\
\hline
\end{tabular}

Coefficient of variation $41.26 \%$

Averages followed by the same capital letter in line and lower case letter in column do not differ between them for Turkey test at $5 \%$ significance.

Anatomical analyses. Visible differences between materials were observed analyzing the base sections of $P$. fortunei var. mikado semihardwood stem cuttings coming from epicormic shoots of adult trees stumps (figure 2A,B), and from epicormic shoots of detached branches, collected in spring/2011.

Materials are found in a secondary growth condition, and cuttings from epicormic shoots of branches present more
Table 3. Percentage of leaves maintenance and shoots emission of $P$. fortunei var. mikado cuttings, coming from epicormic shoots of stumps and branches, submitted to different indolebutyric acid (IBA) treatments.

Porcentaje de mantenimiento de hojas y emisión de brotes en estacas de $P$. fortunei var. mikado, procedentes de brotes epicórmicos de cepas y ramas, sometidas a diferentes concentraciones de ácido indolilbutírico (IBA).

\begin{tabular}{|c|c|c|c|}
\hline \multicolumn{4}{|c|}{ Types of cuttings } \\
\hline $\begin{array}{c}\text { IBA } \\
\text { mg L }^{-1}\end{array}$ & $\begin{array}{c}\text { Epicormic shoots } \\
\text { of stumps }\end{array}$ & $\begin{array}{c}\text { Epicormic shoots } \\
\text { of branches }\end{array}$ & Averages \\
\hline \multicolumn{4}{|c|}{ Maintenance of leaves on cuttings } \\
\hline 0 & $3.12 \quad b \quad B$ & 15.62 a $\mathrm{A}$ & 9.37 \\
\hline 500 & 12.50 a $\mathrm{A}$ & $0.00 \quad \mathrm{~b} \quad \mathrm{~B}$ & 6.25 \\
\hline 1,000 & 3.12 b A & $3.12 \quad \mathrm{~b}$ A & 3.12 \\
\hline 1,500 & 3.12 b A & $0.00 \quad \mathrm{~b} \mathrm{~A}$ & 1.56 \\
\hline 2,000 & 6.25 a b A & $0.00 \quad \mathrm{~b} A$ & 3.12 \\
\hline Averages & 5.62 & 3.75 & \\
\hline \multicolumn{4}{|c|}{ Coefficient of variation $93.82 \%$} \\
\hline \multicolumn{4}{|c|}{ Percentage of cuttings with shoots } \\
\hline 0 & 41.02 & 68.75 & 54.68 a \\
\hline 500 & 59.37 & 62.50 & 60.94 a \\
\hline 1,000 & 50.00 & 46.87 & $48.44 \mathrm{a}$ \\
\hline 1,500 & 43.75 & 68.75 & 56.25 a \\
\hline 2,000 & 53.12 & 56.25 & 54.69 a \\
\hline Averages & $49.37 \mathrm{~A}$ & $60.62 \mathrm{~A}$ & \\
\hline
\end{tabular}

Averages followed by the same capital letter in line and lower case letter in column do not differ between them for Turkey test at $5 \%$ significance.

juvenile tissues when compared to cuttings coming from epicormic shoots of stumps. A multiseriate epidermis was observed in the two materials. In the cuttings coming from stumps there were regions where the cork cambium was beginning to form in the subepidermal layer (figure 2B,D).

In material coming from stumps, cortex is externally composed by seven to nine collenchyma layers and internally by 12 parenchyma layers; while material coming from branches presents a narrower cortical region, with six collenchyma layers and eight parenchymal. Remaining in the cortical region, both materials present bundles of fibers forming a discontinuous ring (figure 2B,D). Meanwhile the material from stumps presents a higher degree of lignification of these cells, with thicker walls and considerably smaller lumen. In material coming from branches, these bundles of fibers are present, though without thickening and lignification of the walls.

The secondary phloem is continuous, in both cuttings types, formed by sieve elements, companion cells and pa- 

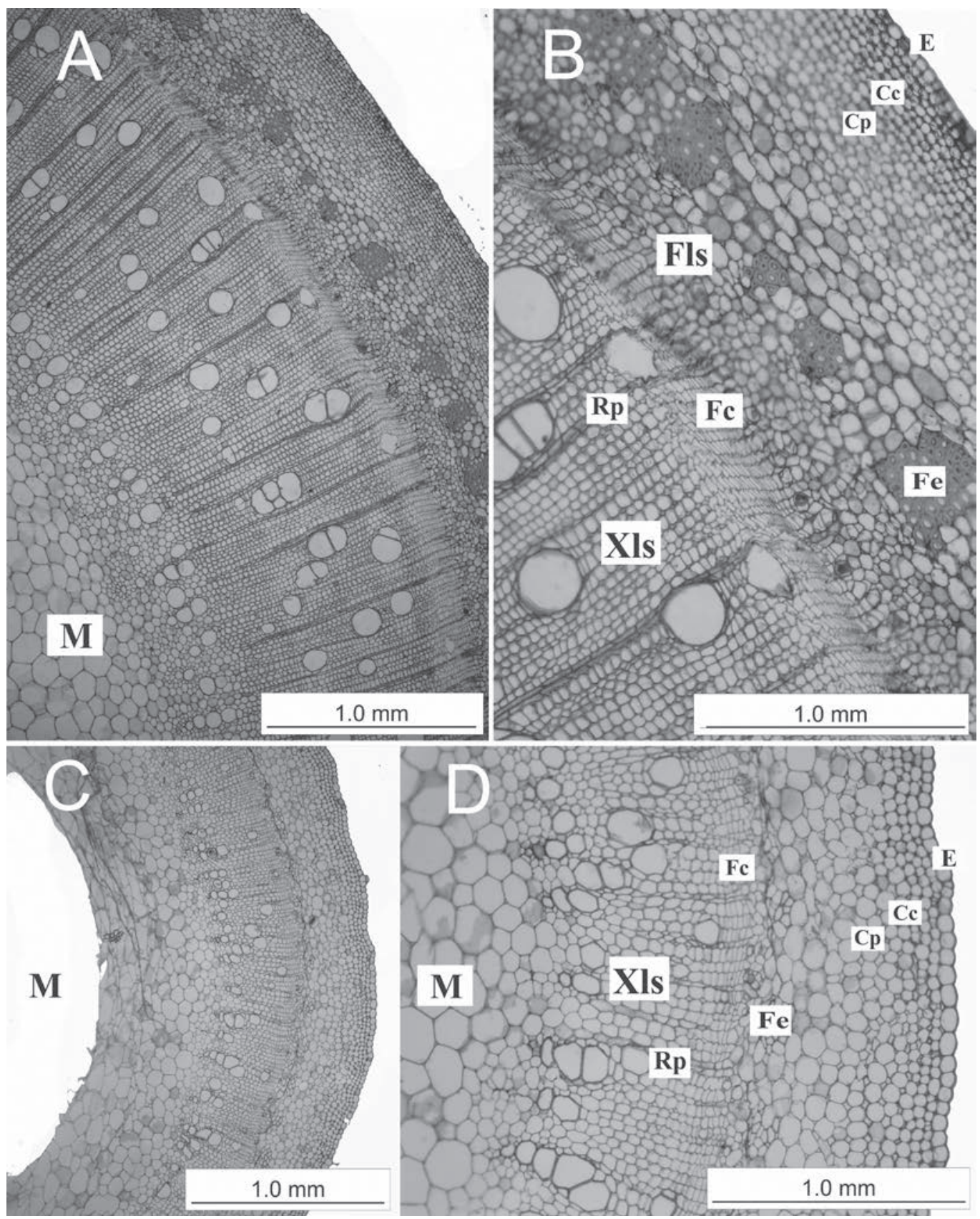

Figure 2. Transversal sections of semi-hardwood stem cuttings, coming from epicormic shoots of stump (A and B) and epicormic shoots of detached branches (C and D) of P. fortunei var. mikado: A- General view of the transversal cut: Medulla (M); B- Epidermis (E), Collenchyma cells (Cc), Parenchyma cells (Cp), Fibers bundle (Fe), Secondary phloem (Fls), Cambium bundle (Fc), Secondary xylem (Xls), Parenchyma rays (Rp); C- General view of the transversal cut: Medulla (M); D- Epidermis (E), Collenchyma cells (Cc), Parenchyma cells (Cp), Fibers bundles (Fe), Secondary phloem (Fls), Cambium bundle (Fc), Secondary xylem (Xls), Parenchyma rays (Rp), Secondary xylem (Xls), Medulla (M).

Secciones transversales de estacas semileñosas, procedentes de brotes epicórmicos de cepas (A y B) y brotes epicórmicos de ramas separadas (C y D), de P. fortunei var. mikado: A- Vista general del corte transversal: Médula (M); B- Epidermis (E), células de colenquima (Cc), células de parénquima (Cp), Agrupamiento de fibras ( $\mathrm{Fe}$ ), floema Secundario (Fls), haz de Cambium ( $\mathrm{Fc}$ ), xilema secundario (xls), haz de parénquima (Rp); C- vista general del corte transversal: médula (M); D- Epidermis (E), células de colenquima (Cc), células de parénquima (Cp), Agrupamiento de fibras (Fe), floema secundario (Fls), haz Cambium ( $\mathrm{Fc}$ ), xilema secundario (xls), rayos de parénquima (Rp), xilema secundario (xls), médula (M). 
renchyma. The fascicular cambium is formed by several layers of undifferentiated cells, making easy to identify a bigger number of vessels in formation when observing material coming from stumps, compared to material coming from branches. It is possible to observe the presence of parenchyma rays in xylem, with 2, 3 or 4 strands of cells, presenting mainly isolated or radially grouped vessel elements, with paratracheal parenchyma and fibers (figure 2C,D).

Medulla is formed by parenchyma in cuttings coming from epicormic shoots of stumps; while in cuttings coming from epicormic shoots of branches it is partially disintegrated, forming a fistula or gap (figure 2A,C). There was no evidence of starch grains and phenolic components in the analyzed material.

\section{DISCUSSION}

Results about rooting suggest that the higher grade of lignification in cuttings coming from stumps, as demonstrated by thicker cellular walls and considerably smaller lumen (figure 2), is responsible for the lower rooting activity. It was suggested that the lignified cuttings possibly presented more rooting difficulties due to a ring of sclerenchyma (not observed in the present study) or due to the physiological lower capacity to form root primordia (Trobec et al. 2005, Hartmann et al. 2011).

Different species present specific structures acting as anatomical barriers, such as fibers and sclereids, in the stem primary phloem, forming a kind of closed ring that prevents the roots system to break through (Lovell and White 1986). In older stems, this prevention can take place due to the presence of a perivascular sclerenchyma sheath. In the species Tectona grandis Linn. F., some anatomical characteristics of the wood, such as number and dimension of fibers and vessels, can be used as markers of the plant juvenility/maturity (Husen and Pal 2006).

The better performance of cuttings originated from epicormic shoots of detached branches can be attributed to morphological differences of the two considered materials. Leaves of epicormic shoots from stump were bigger than the ones from branches, even after the reduction to $78 \mathrm{~cm}^{2}$ (10 cm diameter). This could have caused rooting problems due to excessive transpiration, causing dehydration of cuttings, or even excessive water deposits on leaf blades (umbrella effect). This effect is observable in species with a big leaf surface, when leaves overlay occurs in a greenhouse and the passage of irrigation water to substrate is hindered.

Another factor that could have had influence on the performance of cuttings from stumps is stress, resulting from material transportation and preparation. Even if all possible cares were applied, a certain physiological stress could have taken place, being possibly responsible for the poor performance of these cuttings, compared to the ones from detached branches. This stress could be associated with cuttings bases oxidation, because it has a direct influence on plant materials and generally tends to stimu- late IAA (indoleacetic acid) oxidation, while o-diphenols, p-diphenols and poliphenols inhibit this reaction by influencing the IAA-oxidase system (Lee et al. 1982). Oxidation is mainly influenced by phenolic compounds, often harming the rooting process, though it is essential for plants physiological functions (Hartmann et al. 2011).

About the number of roots per cutting (table 1), the superiority of the cuttings made from stumps is due to the fact that bigger cuttings have a superior carbohydrates reserve that is fundamental to the rhizogenesis process. In clones of Eucalyptus spp., diameter and length of sprouts was one of the factors that influenced the formation of adventitious roots in cuttings (Rosse et al. 1997); and in Toona ciliata M. Roemer, minicuttings coming from bigger shoots had tendency to generate seedlings with even faster development in the same evaluation period (Souza et al. 2009).

The use of plant growth regulators, indolebutyric acid (IBA) in this case, is recommended to stimulate and accelerate the adventitious roots formation process (Singh et al. 2004, Guo et al. 2009), increase the rooting index and increase velocity of formation, quality and uniformity of the root system (Hartmann et al. 2011). Similar results were described by Mayer et al. (2001), who worked with Chinese plum (Prunus mume Sieb. et Zucc.) and observed that the use of IBA increased the average length of roots/cutting.

The percentages of callus formation were visibly higher in cuttings coming from epicormic shoots of stumps, fact that can be attributed to this material being less juvenile when compared to cuttings of epicormic shoots from detached branches, and proved through the anatomical analysis of the two materials (figure 2). The decreasing of rooting potential in forest species is generally consequence of the maturation effects of the plants (Greenwood et al. 2001). In general, cuttings from younger plants or branches have a better rooting performance and a decreased callus formation percentage (Reineke et al. 2002).

Studying the cuttings coming from epicormic shoots of branches, it was observed that as IBA concentrations increased, the percentages of callus decreased, or disappeared. Meanwhile, this does not mean that if the IBA concentrations were further increased, the result would be a much lower callus formation percentage or a much higher roots formation. Concentrations higher than the optimum could harm roots formation because they cause phytotoxicity, with necrosis of the base or even of the entire cutting as a consequence (Woodward and Bartel 2005, Guo et al. 2009).

Furthermore, cuttings coming from shoots of detached branches showed also better rooting indicators when compared to the ones from stumps, demonstrating the fact that this differentiation of the base tissues for the callus formation does not result in a dedifferentiation to form adventitious roots, being roots generated in a direct form.

Concerning $P$. fortunei cuttings survival (table 2), the higher survival indicators of cuttings coming from epicormic shoots of stumps, which may be consequence of the 
higher carbohydrates content in this type of cuttings when compared to the ones coming from epicormic shoots of branches, and when associated with the efficient environmental control into the greenhouse, helped to maintain cuttings alive throughout the experimental period.

According to Nicoloso et al. (1999), a factor with considerable influence on cuttings survival is actually the limitation in quantity of inorganic and organic nutrients reserves in their tissues, in other words, proportionally smaller cuttings have tendency to retain a smaller quantity of these nutrients.

About the percentage of mortality of $P$. fortunei cuttings, the results support the thesis that the higher survival rates in cuttings coming from epicormic shoots of stumps are due to the higher carbohydrates concentrations and higher quantities of stored substances. As a confirmation, regarding cuttings coming from branches, most of those that did not form roots actually died, and very few of them survived in the greenhouse until the end of the experimental period; differently from the cuttings from stumps, which survived almost entirely until the end of the experiment.

One factor that could have increased the mortality of cuttings coming from epicormic shoots of stumps is related to the umbrella effect, where the presence of leaves could prevent water from reaching the substrate, and create a water stress to cuttings, giving room to an early mortality, mainly during the first five days of the experiment, before leaves started to fall.

In both cutting types it was observed that, at a certain moment, leaves started their natural fall, and that by the end of the experimental period, a small percentage had preserved at least one of the original leaves. Meanwhile it was observed that the beginning of leaves falling started one week after the installation and the process lasted until the final evaluation; in other words 60 days after the installation. This fact demonstrates the importance of leaves maintenance in cuttings, even for a limited period of time, because it helps the rhizogenesis process through provision of mainly carbohydrates and plant hormones (Mesén et al. 2001).

The carbohydrates produced are important for cutting survival, providing better physiological conditions throughout the rooting process, mainly providing the necessary energy for the adventitious roots formation process (Roland et al. 2006).

In general, the maintenance of leaves is related to the rooting formation process, where all the synthesized metabolites from the stock plant can be transported to the rooting region after the cuttings preparation, and plays a role in the cuttings water status regulation (Xavier et al. 2009).

Although there were no significant differences between the averages of treatments, it was possible to verify that there was a large percentage of shoots emissions in both types of cuttings, confirming that in general terms, all the cuttings that had lost their leaves, subsequently emitted lateral shoots. This could be due to the break of the apical dominance driven by leaves maintenance, hence when leaves fall this dominance ends and shoots are subsequently emitted. Pio et al. (2005), working with cutting of olive trees (Olea europaea L.), verified that the lack of leaves in cuttings, or even the fall of leaves during the rooting process, caused a stimulus to new shoots emission from the auxiliary buds located in the base of the leaves petioles, which otherwise remained dormant.

\section{CONCLUSIONS}

Based on the results obtained in this study it is possible to conclude that: cuttings coming from epicormic shoots of detached branches are more indicated for $P$. fortunei var. mikado rooting when compared to shoots of stumps. There are no positive effects from the application of indolebutyric acid (IBA) to induce adventitious roots formation. Anatomical differences observed in the two types of cuttings had no influence on shoots formation and on new roots emission in cuttings of dragon tree.

\section{REFERENCES}

Bergmann BA, HK Moon. 1997. In vitro adventitious shoot production in Paulownia. Plant Cell Reports 16: 315-319. DOI: $10.1007 / B F 01088288$.

Borges Júnior N, MP Martins-Corder, RC Sobrosa, EM Santos. 2004. Rebrota de cepas de árvores adultas de acácia-negra (Acacia mearnsii De Wild.). Revista Árvore 28: 611-615. DOI: 10.1590/S0100-67622004000400015.

Golle DP, LRS Reiniger, AR Curti, CB Bevilacqua. 2009. Melhoramento florestal: ênfase na aplicação da biotecnologia. Ciência Rural 39: 1607-1614. DOI: 10.1590/S010384782009000500050.

Greenwood MS, X Cui, F Xu. 2001. Response to auxin changes during maturation-related loss of adventitious rooting competence in loblolly pine (Pinus taeda) stem cuttings. Physiol Plant 111: 373-380. DOI: 10.1034/j.13993054.2001.1110315.x.

Guo X.F, XL Fu, DK Zang, Y Ma. 2009. Effect of auxin treatments, cuttings' collection date and initial characteristics on Paeonia 'Yang Fei Chu Yu' cutting propagation. Scientia Horticulturae 119: 177-181. DOI: 10.1016/j.scienta.2008.07.022.

Hartmann HT, DE Kester. 2011. Hartmann and Kerster's PLANT PROPAGATION: principles and practices. 8. ed. Boston, USA. Prentice Hall. 915 p.

Husen A, M Pal. 2006. Variation in shoot anatomy and rooting behaviour of stem cutting in relation to age of donor plants in teak (Tectona grandis Linn. F). New Forest 31: 57-73. DOI: 10.1007/s11056-004-6794-5.

Johansen DA. 1940. Plant Microtechnique. New York, USA. McGraw-Hill. 523 p.

Kumar MB, RE Barker, BM Reed. 1999. Morphological and molecular analysis of genetic stability in micropropagated Fragaria x Ananassa cv. Pocahontas. Vitro Cellular e Developmental Biology. Plant 35: 254-258. DOI: 10.1007/ s11627-999-0088-8.

Lee TT, AN Starratt, JJ Jevnikar. 1982. Regulation of enzymic oxidation of indole-3-acetic acid by phenols: structure- 
activity relationships. Phytochemistry 21: 517-523. DOI: 10.1016/0031-9422(82)83132-4.

Lovell J, PH White. 1986. Anatomical changes during adventitious root formation. In Jackson MB ed. New root formation in plants and cuttings. Dordrecht, The Netherlands. Martinus Nijhoff Publishers. p. 111-140.

Mayer NA, FM Pereira, JC Nachtigal. 2001. Propagação do umezeiro (Prunus mume Sieb e Zucc.) por estaquia herbácea. Revista Brasileira de Fruticultura 23: 673-676. DOI: 10.1590/S0100-29452001000300046.

Mesén F, RRB Leakey, AC Newton. 2001. The influence of stockplant environment on morphology, physiology and rooting of leafy stem cuttings of Albizzia guachapele. New Forests 22: 213-227. DOI: 10.1023/A:1015668011884.

Nicoloso FT, RP Fortunato, MAF Fogaça. 1999. Influencia da posição da estaca no ramo sobre o enraizamento de Pfaffia glomerata (Spreng.) Pedersen em dois substratos. Ciência Rural 29: 277-283. DOI: 10.1590/S010384781999000200015.

Pio R, DC Bastos, AJ Berti, JA Scarpare Filho, FAA Mourão Filho, FA Entelmann, ASR Alves, JE Bettiol Neto. 2005. Enraizamento de diferentes tipos de estacas de oliveira (Olea europaea L.) utilizando ácido indol butírico. Ciência Agrotecnológica 29: 562-567. DOI: 10.1590/S141370542005000300008.

Reineke RA, WP Hackett, AG Smith. 2002. Lignification associated with decreased adventitious rooting competence of English ivy petioles. Journal of Environmental Horticulture 20: 236-239.

Roland F, E Baena-Gonzalez, J Sheen. 2006. Sugar sensing and signaling in plants: conserved and novel mechanisms. Annual Review Plant Biology 57: 675-709. DOI: 10.1146/ annurev.arplant.57.032905.105441.

Rosse LN, AC Davide, FLG Bertolucci, MAP Ramalho. 1997. Influência da idade e da época de abate na brotação das cepas e no enraizamento de estacas em clones de Eucalyptus sp. Revista Cerne 3: 117-128.

Souza JCAV, DG Barroso, JGA Carneiro, SL Teixeira, E Balbinot. 2009. Propagação vegetativa de cedro-australiano (Toona ciliata M. Roemer) por miniestaquia. Revista Árvore 33: 205-213. DOI: 10.1590/S0100-67622009000200002.

Trobec M, F Stampar, R Veberic, G Osterc. 2005. Fluctuations of different endogenous phenolic compounds and cinnamic acid in the first days of the rooting process of cherry rootstock 'Gisela 5' leafy cuttings. Journal of Plant Physiology 162: 589-597. DOI: 10.1016/j.jplph.2004.10.009.

Wendling I, A Xavier. 2003. Miniestaquia seriada no rejuvenescimento de clones de Eucalyptus. Pesquisa Agropecuária Brasileira 38: 475-480. DOI: 10.1590/S0100204X2003000400005.

Wendling I, GE Brondani, A Biassio, LF Dutra. 2013. Vegetative propagation of adult Ilex paraguariensis trees through epicormic shoots. Acta Scientiarum 35: 117-125. DOI: 10.4025/actasciagron.v35i1.15958.

Woodward AW, B Bartel. 2005. Auxin: regulation, action, and interaction. Annals of Botany 95: 707-735. DOI: 10.1093/ aob/mci083.

Xavier A, I Wendling, RL Silva. 2009. Silvicultura clonal: princípios e técnicas. Viçosa, Brazil. Universidade Federal de Viçosa. 272 p.

Zhu ZH, XY Lu, YG Xiong. 1986. Paulownia in china: cultivation and utilization. Singapore: Asia Network for Biological Science. Ottawa, Canada. International Development Research Centre. 451 p. 
